\title{
MANAJEMEN LABA DALAM SUDUT PANDANG ETIKA BISNIS ISLAM
}

\author{
Indah Muliasari dan Dalili Dianati \\ Program Studi Akuntansi Syariah \\ Sekolah Tinggi Ekonomi Islam SEBI \\ Email: muliasari.indah@gmail.com
}

\begin{abstract}
Earnings management in this study are based on the opinion of Schipper that said earnings management as managerial engineering undertaken by management to deliberately intervene in the process of determining earnings or financial reporting by utilizing techniques and accounting policy for a particular purpose. This study aims to examine and analyze the point of view of Islamic business ethics on the practice of earnings management. This study used a qualitative descriptive methods, data collection technique, study of literatures and interviews. The results showed that earnings management is not in accordance with Islamic business ethics. Islamic business ethics contains the values of tauhid, unity; fair, equilibrium; freedom; responsibility; ihsan, benevolence.
\end{abstract}

Keywords: earnings management, Islamic business ethics

\section{PENDAHULUAN}

Laporan keuangan merupakan suatu hal yang sangat krusial bagi sebuah perusahaan dan stakeholder lainnya karena merupakan alat yang sangat penting untuk mendapatkan informasi sehubungan dengan posisi keuangan dan hasilhasil yang telah dicapai oleh sebuah perusahaan. Dalam Pernyataan Standar Akuntansi Keuangan (PSAK) yang dinyatakan dalam PSAK 101 paragraf 8 baris ke 31 disebutkan bahwa laporan keuangan adalah suatu penyajian terstruktur dari posisi keuangan dan kinerja keuangan dari suatu entitas (syariah). Tujuan laporan keuangan untuk tujuan umum adalah memberikan informasi tentang posisi keuangan, kinerja dan arus kas yang bermanfaat bagi sebagian besar kalangan pengguna laporan dalam rangka membuat keputusankeputusan ekonomi serta menunjukkan pertanggungjawaban (stewardship) manajemen atas sumber-sumber daya yang dipercayakan kepada manajemen tersebut. Laporan keuangan tersebut diharapkan dapat memberikan informasi kepada para investor dan kreditor dalam mengambil keputusan yang berkaitan dengan investasi dana mereka. Laba telah digunakan sebagai salah satu pola dalam pengukuran kinerja yang merupakan bagian dari laporan keuangan yang menunjukkan peningkatan atau penurunan ekuitas dari berbagai sumber transaksi kecuali transaksi dengan pemegang saham.

Informasi tentang laba telah digunakan sebagai salah satu pengukur kinerja dan alat dalam pengambilan keputusan yang memiliki fleksibilitas yang diberikan oleh prinsip akuntansi yang berterima umum (PABU) (Suhendro, 2006). Informasi laba ini dalam praktiknya dapat memengaruhi perilaku para pemakai 
informasi laporan keuangan, khususnya pihak investor dan kreditor. Informasi laba ini dibutuhkan oleh investor dan kreditor sebagai dasar keputusan terhadap tingkat pengembalian modal yang mereka investasikan (Marzuqi \& Latif, 2010). Selain investor dan kreditor, informasi laba tidak kalah pentingnya bagi manajer, hal ini disebabkan informasi laba atau laba historis berguna untuk mengukur efisiensi manajemen, membantu memprediksi keadaan usaha dan distribusi deviden di masa yang akan datang, mengukur keberhasilan manajemen, serta sebagai acuan pengambilan keputusan ekonomis di masa yang akan datang (Hendriksen \& Breda, 1992 dalam Wahyuningsih, 2007). Dalam hal ini, manajer sebagai pengelola perusahaan lebih banyak mengetahui informasi internal dan prospek perusahaan di masa yang akan datang dibandingkan pemilik (pemegang saham). Oleh karena itu sebagai pengelola, manajer berkewajiban memberikan sinyal mengenai kondisi perusahaan kepada pemilik. Akan tetapi informasi yang disampaikan terkadang tidak sesuai dengan kondisi perusahaan sebenarnya. Kondisi ini dikenal sebagai informasi yang tidak simetris atau asimetri informasi (information asymmetric) (Haris, 2004 dalam Simposium Nasional Akuntansi X, Unhas Makasar 26-28 Juli 2007).

Ketika asimetri informasi tinggi, stakeholder tidak memiliki sumber daya yang cukup, insentif, atau akses atas informasi yang relevan untuk memonitor tindakan manajer, hal ini memberikan kesempatan untuk terjadinya praktik manajemen laba. Adanya asimetri informasi akan mendorong manajer untuk menyajikan informasi yang tidak sebenarnya terutama jika informasi tersebut berkaitan dengan pengukuran kinerja manajer (Halim, Meiden, Tobing, 2005).

Manajemen laba tersebut merupakan bentuk intervensi manajemen dalam penyusunan laporan keuangan. Intervensi yang dilakukan melalui manipulasi terhadap angka-angka akuntansi yang dilaporkan memunculkan berbagai skandal akuntansi, seperti pada kasus transaksi off-balance sheet Enron Energy tahun 2000, kasus peningkatan pendapatan Xerox tahun 1997-2000 dan sebagainya. Di Indonesia, hal ini pun pernah menjadi isu, seperti antara lain pada kasus mark up laba Kimia Farma tahun 2001 dan kasus pembukuan ganda Lippo Bank tahun 2002 (Inggarwati \& Kaudin, 2010).

Dalam perspektif dan argumentasi yang berbeda, beberapa pihak menyatakan pendapat secara berbeda pula. Pada satu pihak, manajemen laba bukanlah bentuk tindakan manipulasi laba apabila masih dilakukan dalam koridor prinsip akuntansi berterima umum. Pada sisi yang lain, manajemen laba merupakan bentuk tindakan manipulasi laba, karena manajemen laba selalu dilandasi oleh motivasi untuk memperoleh keuntungan pribadi dengan cara memberikan gambaran tentang kinerja perusahaan yang tidak sebenarnya, meskipun kinerja yang digambarkan adalah kinerja jangka pendek (Riduwan, 2010).

Jika angka-angka laporan keuangan (khususnya angka laba) direkayasa untuk memenuhi kepentingan manajer, sementara kepentingan pihak lain (misalnya investor dan kreditor) diabaikan, maka informasi laba sudah tidak netral lagi, yang berarti bertentangan dengan konsep netralitas yang dirumuskan dalam Kerangka Dasar Penyusunan dan Penyajian Laporan Keuangan 
(KDPPLK). Hasil beberapa penelitian akademik banyak mengungkapkan bahwa praktik manajemen laba merupakan sebuah faktisitas. ${ }^{1}$ Sementara itu, terdapat pandangan umum, sebagai pandangan arus utama (mainstream), bahwa sepanjang dilakukan tanpa melanggar standar akuntansi, praktik manajemen laba adalah sah dan tidak dapat disebut sebagai tindak kecurangan. Pandangan mainstream ini mendominasi dan merepresi pandangan minoritas yang menentang praktik manajemen laba yang dalam perspektif mereka apa pun pola dan strateginya, manajemen laba merupakan tindak kecurangan yang terdorong oleh pikiran koruptif (Riduwan, 2010).

Sehubungan dengan kontroversi mengenai manajemen laba, dilihat dalam perspektif etika, manajemen laba merupakan salah satu masalah penting dalam dunia bisnis. Pelaksanaan aktivitas manajemen menimbulkan pertanyaan mengenai etika bagi manajemen sebab memiliki pengaruh pada manajer dan perusahaannya (Burns dan Merchant, 1990 dalam Kawedar, 2005). Etika dalam Islam menganjurkan kepada manusia untuk menghadirkan kedamaian, kejujuran, dan keadilan. Etika bekerja dalam Islam juga mengajarkan agar manusia dalam menjalankan pekerjaannya dilakukan dengan jujur dan amanah (tidak mengambil sesuatu yang bukan haknya, tidak curang, objektif dalam menilai) serta tidak melanggar prinsip-prinsip syariah. Berdasarkan uraian di atas, penelitian ini akan memaparkan dan mengekplorasi Manajemen Laba Dalam Sudut Pandang Etika Bisnis Islam, ini dirasa penting berdasarkan banyaknya kontroversi yang terjadi akan manajemen laba baik dari sisi akuntansi maupun dari segi etika. Selain itu, penelitian tentang manajemen laba dalam sudut pandang etika bisnis Islam masih terbilang jarang, hal ini menjadi topik yang menarik bagi penulis untuk melakukan penelitian. ${ }^{1}$

\section{LANDASAN TEORI}

\subsection{PENGERTIAN MANAJEMEN}

Ricky W. Griffin mendefinisikan manajemen sebagai sebuah proses perencanaan, pengorganisasian, dan pengontrolan sumber daya untuk mencapai sasaran (goals) secara efektif dan efisien. Adapun menurut James, manajemen adalah kebiasaan yang dilakukan secara sadar dan terus menerus dalam membentuk organisasi. Sedangkan menurut Stephen P. Robbins dan Mary Coulter (2007) manajemen adalah proses mengoordinasikan aktivitas-aktivitas kerja sehingga dapat selesai secara efisien dan efektif dengan dan melalui orang lain.

Subramanyam \& Wild (2010) menyebutkan bahwa manajer merupakan pihak yang paling bertangggungjawab atas laporan keuangan yang wajar dan

\footnotetext{
1 Faktisitas merupakan situasi manusia yang tidak tergantung pada kehendaknya, misalnya manusia tidak bisa memilih adanya sendiri, bahwa ia tidak memilih lahir sebagai orang indonesia, sebagai laki-laki atau perempuan. Faktisitas ini membuat manusia melihat sesuatu secara berlainan. Dalam kaitannya dengan manajemen laba, adanya faktisitas ini membuat manusia memandang manajemen laba dengan cara yang berberda, ada yang memandang manajemen laba adalah hal yang sah dan bukan tindak kecurangan, ada pula yang men entang manajemen laba ini karena dianggap sebagai tindak kecurangan.
} 
akurat. Manajer memiliki kontrol utama atas integritas sistem akuntansi dan catatan keuangan yang digunakan untuk membuat laporan keuangan. Sehubungan dengan fakta ini, Perjanjian Undang-Undang Sabarnes-Oxley (Sarbanes Oxley Act-SOx) ${ }^{1}$ tahun 2002 mengharuskan Chief Executive Officer (CEO) untuk secara pribadi menjamin keakuratan dan verifikasi laporan keuangnnya.

\subsection{PENGERTIAN LABA}

Subramanyam \& Wild (2010) menjelaskan bahwa laba (income atau disebut juga earning atau profit) merupakan rigkasan hasil bersih aktivitas operasi usaha dalam periode tertentu yang dinyatakan dalam istilah keuangan. Laba merupakan informasi perusahaan paling diminati dalam pasar uang. Pada konsepnya, laba merupakan pengukuran perubahan kekayaan pemegang saham pada periode maupun mengestimasi laba usaha sekarang, yaitu sampai sejauh mana perusahaaan dapat menutupi biaya operasi dan menghasilkan pengembalian kepada pemegang sahamnya, secara khusus, laba berperan sebagai indikator profitabilitas perusahaan.

\subsection{MANAJEMEN LABA}

Sampai saat ini banyak penulis mendefinisikan manajemen laba secara berbeda. Beberapa referensi menunjukkan istilah lain, seperti magic accounting, cosmetic accounting, financial shenanigan, dan creative accounting. Earnings management has been defined by Schipper as ....purposeful intervention in the external financial reporting process, with the intent of obtaining some private gain (Schipper, 1989 dalam Work \& Tearny, 1997) dalam arti, manajemen laba sebagai intervensi manajemen dengan sengaja dalam proses penentuan laba/proses pelaporan keuangan, biasanya untuk memenuhi tujuan pribadi. Healy \& Wahlen (1999) dalam Dechow \& Skinner (2000) mendefinisikan manajemen laba sebagai "earnings management occurs when managers use judgment in financial reporting and in structuring transactions to alter financial reports to either mislead some stakeholders about the underlying economic performance of the company, or to influence contractual outcomes that depend on reported accounting numbers."

Dalam artian manajemen laba terjadi ketika manajer melakukan penilaian dalam pelaporan keuangan dan menyusun transaksi untuk mengubah laporan keuangan dengan tujuan menyesatkan para stakeholder mengenai performa ekonomi suatu perusahaan atau untuk memengaruhi hasil perjanjian yang tergantung pada angka akuntansi yang dilaporkan.

\subsubsection{Bentuk-Bentuk Manajemen Laba}

Scott (1997) dalam buku Creative Accounting (Sulistiawan, Januarsi, Alvia, 2011) merangkum bentuk umum yang digunakan dalam praktik manajemen laba, yaitu:

1. Taking a Bath

2. Income Minimization

3. Income Maximization 
3. Income Smoothing

4. Timing Revenue and Expenses Recognation

\subsubsection{Motivasi Manajemen Laba}

Secara umum terdapat beberapa hal yang memotivasi individu atau badan usaha melakukan tindakan manajemen laba, diantaranya adalah sebagai berikut (Scott, 1997 dalam Sulistiawan, Januarsi, Alvia, 2011):

1. Motivasi Bonus

2. Motivasi Utang

3. Motivasi Pajak

4. Motivasi Penjualan Saham

5. Motivasi Pergantian Direksi

6. Motivasi Politis

\subsubsection{Teknik Manajemen Laba}

Teknik manajemen laba sangat beragam, mulai dari teknik legal dalam artian manajemen memilih metode akuntansi yang dibolehkan SAK sampai teknik ilegal yang bertentangan dan tidak dibolehkan SAK (Wolk, Dodd, dan Tearney, 2006 dalam Sulistiawan, Januarsi, Alvia, 2011).

1. Mengubah Metode Akuntansi

2. Membuat Estimasi Akuntansi

3. Mengubah Periode Pengakuan Pendapatan dan Biaya

4. Mereklasifikasi Akun

5. Mereklasifikasi Akrual Diskresioner dan Akrual Nondiskresioner

\subsection{TEORI KEAGENAN}

Jensen dan Meckling (1976) memberikan definisi mengenai hubungan antara agensi dan pemegang saham sebagai sebuah hubungan antara satu orang atau lebih (principal) yang mempekerjakan orang lain (agen) untuk memberikan suatu jasa dan kemudian mendelegasikan wewenang pengambilan keputusan kepada agen tersebut.

Dalam Stephen A. Ross (1973 hlm. 134)

Agency relationship has arisen between two (or more) parties when one, designated as the agent, acts for, on behalf of, or as representative for the other, designated the principal, in a particular domain of decision problems.

Sehubungan dengan definisi dari Jensen dan Meckling, Sutedi (2012) memberikan penjelasan bahwa konflik kepentingan (the agent will not always act in the best interest of the principal) tersebut memicu terjadinya biaya agensi. Biaya agensi yang timbul dari konflik kepentingan antara pengelola perusahaan (agent) dengan pemegang saham (principal) berpotensi menimbulkan jenis biaya agensi.

Menurut teori agensi, agent harus bertindak secara rasional untuk kepentingan principal-nya. Agen harus menggunakan keahlian, kebijaksanaan, itikad baik, dan tingkah laku yang wajar dan adil dalam memimpin perseroan 
(Wilamarta, 2002 dalam Surya \& Yustiavandana, 2008). Dalam praktik timbul masalah (agency problem), karena ada kesenjangan kepentingan antara para pemegang saham sebagai pemilik perusahaan dengan pihak pengurus atau manajemen sebagai agen. Pemilik memiliki kepentingan agar dana yang telah diinvestasikannya memberikan pendapatan (return) yang maksimal. Sedangkan pihak pengelolaan dana memiliki kepentingan terhadap perolehan incentives atas pengelolaan dana pemilik perusahaan (Alijoyo \& Zaini, 2004 dalam Surya \& Yustiavandana, 2008). Konflik kepentingan ini menimbulkan biaya (cost), yang muncul dari ketidaksempurnaan penyusunan kontrak antara agents dan principals, karena adaya informasi yang asimetris. ${ }^{2}$

\subsection{TEORI GOOD CORPORATE GOVERNANCE}

Teori good corporate governance erat kaitannya dengan pengertian corporate governance. Corporate governance dapat didefinisikan sebagai seperangkat peraturan yang mengatur hubungan antara pemegang saham, pengurus (pengelola) perusahaan, pihak direktur, pemerintah, karyawan serta para pemegang kepentingan intern dan ekstern lainnya yang berkaitan dengan hakhak dan kewajiban mereka atau dengan kata lain suatu sistem yang mengatur dan megendalikan perusahaan (Sutedi, 2012).

Secara sederhana, Good Corporate Governance (GCG) merupakan sistem yang untuk menciptakan nilai tambah bagi semua stakeholder. Dua hal yang sangat ditekankan dalam konsep ini adalah, pertama, pentingnya hak pemegang saham untuk memperoleh informasi dengan benar (akurat) dan tepat pada waktunya, kedua, kewajiban perusahaan untuk melakukan pengungkapan (disclosure) secara akurat, tepat waktu, dan transparans terhadap semua informasi kinerja perusahaan, kepemilikan, dan stakholder. Ada empat komponen utama yang diperlukan dalam konsep GCG, yaitu fairness, transparancy, accountability, dan responsibility (Sutedi, 2012).

Dengan tujuan untuk menciptakan nilai tambah bagi semua pihak yang berkepentingan, GCG diharapkan dapat meminimalisasi adanya asimetri informasi sehingga akan memperkecil kemungkinan dilakukannya manajemen laba. Secara prinsipil, manipulasi dalam manajemen laba tidak sejalan dengan semangat GCG (Sutedi, 2012).

\subsection{LAPORAN KEUANGAN}

Laporan keuangan merupakan sarana pengomunikasian informasi keuangan utama di dalam sebuah korporasi kepada pihak-pihak diluar korporasi. Laporan ini menampilkan sejarah perusahaan yang dikuantifiaksi dalam nilai moneter (Kieso, Weygandt, Warfield, 2002). Laporan keuangan merupakan output dan hasil akhir dari proses akuntansi yang menjadi bahan informasi bagi para pemakainya sebagai salah satu bahan dalam proses pengambilan keputusan. Di samping sebagai informasi, laporan keuangan juga sebagai pertanggungjawaban atau accountability sekaligus menggambarkan indikator kesuksesan suatu perusahaan dalam mencapai tujuannya (Harahap, 2011). 
Menurut Standar Akuntansi Keuangan (SAK), laporan keuangan memiliki tujuan untuk menyediakan informasi yang menyangkut posisi keuangan, kinerja, serta perubahan posisi keuangan suatu perusahaan yang bermanfaat bagi sejumlah besar pemakai dalam pengambilan keputusan ekonomi (Harahap, 2011)..

\subsection{PENGERTIAN ETIKA}

Etika adalah istilah filosofis yang berasal dari kata Yunani "ethos" yang berarti karakter atau kebiasaan. Definisi ini berhubungan erat dengan kepemimpinan efektif dalam organisasi, mengandung arti sebuah kode organisasi yang menyampaikan integritas moral dan nilai yang konsisten dalam melayani publik.

Ethics may be defined as the set of moral principles that distinguish what is right from what is wrong. It is a normative field because it prescribes what one should do or abstain from doing (Beekun, 1996). Etika dapat didefinisikan sebagai seperangkat prinsip moral yang membedakan mana yang benar dan mana yang salah. Etika tersebut merupakan suatu hal yang normatif karena menentukan apa yang harus dilakukan atau tidak dilakukan. Ada tiga arti etika, (1) nilai-nilai dan norma-norma moral yan menjadi pegangan bagi seseorang atau kelompok dalam mengatur tingkah lakunya; (2) kumpulan asas atau nilai moral; (3) ilmu tentang yang baik atau buruk (Harahap, 2011).

Etika dengan segala kaitannya dengan perilaku etis, moralitas dan nilainilai yang terkandung di dalamnya merupakan panduan yang dapat digunakan untuk menilai suatu sikap dan perilaku. Selain untuk menilai, etika juga digunakan sebagai prinsip dan panduan untuk mengatur sikap dna perilaku agar tetap pada jalur nilai-nilai etika itu sendiri.

\subsection{ETIKA BISNIS SECARA UMUM}

Beekun (1996) dalam (Badroen, Suhendra, Mufraeni, Bashori, 2007) menyebutkan bahwa "learning what is right or wrong, and then doing the right thing. Right thing based on moral principle, and other believe the right thing to do depends on the situation". Dengan mempelajari etika bisnis berarti belajar benar atau salah yang dapat membekali seseorang untuk berbuat suatu hal yang benar didasari oleh ilmu, kesadaran, dan kondisi yang berbasis moralitas. Namun terkadang etika bisnis dapat berarti juga etika manajerial (management ethics) atau etika organisasional yang disepakati oleh sebuah perusahaan.

\subsection{ETIKA BISNIS ISLAM}

Dalam hal agama, Islam merupakan sumber nilai dan etika dalam segala aspek kehidupan manusia secara menyeluruh, termasuk wacana bisnis. Islam memiliki wawasan yang komprehensif tentang etika bisnis. Mulai dari prinsip dasar, pokok-pokok kerusakan dalam perdagangan, faktor-faktor produksi, tenaga kerja, modal organisasi, distribusi kekayaan, masalah upah, barang dan jasa, kualifikasi dalam bisnis, sampai kepada etika sosio ekonomik menyangkut hak milik dan hubungan sosial (Putra \& Durachman, 2009). Dalam ajaran Islam, etika bisnis dalam Islam dibangun atau dilandasi oleh aksioma-aksioma, yaitu: tauhid, unity 
(kesatuan, keutuhan); adil, equilibrium (keseimbangan, harmoni); free will (kebebasan); responsibility (tanggung jawab); ihsan dan benevolence (kemanfaatan) (Beekun, 1996).

1. Tauhid, unity (kesatuan, keutuhan)

2. Adil, equilibrium (keseimbangan, harmoni)

3. Free will (kebebasan)

4. Responsibility (tanggung jawab)

5. Ihsan, benevolence (kemanfaatan)

Menurut Beekun (1992: 20) dalam Harahap (2011), beberapa parameter sistem etika Islam adalah sebagai berikut.

1. Setiap keputusan dan tindakan didasarkan pada niat. Niat, tindakan, dan hasil harus halal. Niat yang halal tidak dapat mengubah tindakan yang haram menjadi halal.

2. Setiap tindakan baik adalah ibadah.

3. Islam memberi kebebasan kepada setiap orang, tetapi tidak boleh mengorbankan akuntabilitas dan keadilan.

4. Islam mewajibkan setiap orang hanya tunduk kepada Allah SWT, bukan kepada yang lain.

5. Keputusan yang menguntungkan kelompok mayoritas ataupun minoritas tidak secara langsung berarti bersifat etis, etika bukan permainan mengenai jumlah.

6. Islam adalah sistem yang terbuka pada etika, tidak berorientasi pribadi dan tidak egois.

7. Keputusan etis didasarkan pada pembacaan Al-Quran dan hukum alam.

8. Islam mendorong umat manusia untuk melaksanakan tazkiyah (proses pembersihan secara terus menerus) melalaui partisipasi aktif dalam kehidupan dengan berperilaku etis di tengah ujian dunia.

\subsection{URGENSI ETIKA BISNIS ISLAM}

Munculnya wacana pemikiran etika bisnis, didorong oleh realitas bisnis yang mengabaikan nilai-nilai moralitas. Bagi sebagian pihak, bisnis adalah aktivitas ekonomi manusia yang bertujuan mencari laba semata-mata. Karena itu, cara apapun boleh dilakukan demi meraih tujuan tersebut. Konsekuensinya bagi pihak ini, aspek moralitas tidak bisa digunakan dalam menjalankan bisnis. Aspek moralitas dalam persaingan bisnis, dianggap akan menghalangi kesuksesannya. Pada satu sisi, aktivitas bisnis dimaksudkan untuk mencari keuntungan sebesarbesarnya, sementara prinsip-prinsip moralitas "membatasi" aktivitas bisnis.

Berlawanan dengan kelompok pertama, kelompok kedua berpendapat bahwa bisnis bisa disatukan dengan etika. Kalangan ini beralasan bahwa etika merupakan alasan-alasan rasional tentang semua tindakan manusia dalam semua aspek kehidupannya, tak terkecuali aktivitas bisnis.

Selain itu, dalam realitas bisnis kekinian terdapat ke cenderungan bisnis yang mengabaikan etika. Persaingan dalam dunia bisnis adalah persaingan kekuatan modal. Sementara itu, pemikiran etika bisnis Islam muncul ke permukaan, dengan landasan bahwa Islam adalah agama yang sempurna. Islam 
merupakan agama yang memberikan cara hidup terpadu mengenai aturan-aturan aspek sosial, budaya, ekonomi, sipil, ekonomi dan politik. Dalam Harahap (2011) disebutkan akhlak sudah built in dalam pandangan hidup dan perilaku seorang muslim. Islam itu kafah dan integrated comprehensive atau holistic tidak membedakan sektor ibadah, politik, ekonomi, sosial, dan bisnis.

Di tahun 1999, jurnal Business and Society Review menulis bahwa 300 perusahaan besar yang terbukti melakukan komitmen dengan publik yang berlandaskan pada kode etik akan meningkatkan market value added sampai dua-tiga kali daripada perusahaan lain yang tidak melakukan hal serupa. Bukti lain, seperti riset yang dilakukan oleh DePaul University di tahun 1997, menemukan bahwa perusahaan yang merumuskan komitmen korporat mereka dalam menjalankan prinsip-prinsip etika memiliki kinerja finansial (berdasar penjualan tahunan/revenue) yang lebih bagus dari perusahaan lain yang tidak melakukana hal serupa.

Dalam Syahatah \& Adh-Dhahir (2005) Larrt Axlineg di Amerika melakukan sebuah studi yang membedakan antara perusahaan yang menjunjung tinggi nilai-nilai moral dan tunduk kepada responsibilitas sosial, dengan perusahaan yang tidak menjalankan prioritas akan etika ini. Hasilnya yaitu pertumbuhan keuntungan rata-rata pertahunnya pada kasus pertama berkisar antara $11 \%$, sementara pada kasus kedua berkisar antara 6\%. Studi lapangan tersebut menunjukkan bahwa kuatnya pemberdayaan etika yang unggul dapat membawa nama baik perusahaan, firma, atau badan hukum tersebut. Hal ini akhirnya akan mengarah pada bertambahnya keuntungan, produktivitas yang pesat, dan value added bagi perusahaan.

\section{METODOLOGI PENELITIAN}

\subsection{METODE PENELITIAN}

Dalam Juliansyah Noor (2011) disebutkan bahwa penelitian deskriptif adalah penelitian yang berusaha mendeskripsikan suatu gejala, peristiwa, kejadian yang terjadi saat sekarang. Penelitian deskriptif memusatkan perhatian pada masalah aktual sebagaimana adanya pada saat penelitian berlangsung. Melalui penelitian deskriptif, peneliti berusaha mendeskripsikan peristiwa dan kejadian yang menjadi pusat perhatian tanpa memberikan perlakuan khusus terhadap peristiwa tersebut.

Berdasarkan penjelasan di atas, penelitian ini merupakan penelitian deskriptif kualitatif, yaitu penelitian kualitatif yang menggunakan metode penelitian deskriptif. Sehingga nantinya data yang dikumpulkan berupa katakata dan gambar-gambar, laporan penelitian akan berisi kutipan-kutipan data untuk memberi gambaran penyajian laporan tersebut.

\subsection{DATA PENELITIAN}

Sumber data yang digunakan dalam penyusunan penelitian ini adalah data primer dan data sekunder. Data primer merupakan data yang langsung diperoleh 
oleh pengumpul data dan perlu dilakukan pengolahan untuk dapat digunakan, data sekunder merupakan data yang tidak langsung diberikan kepada pengumpul data, misalnya melalui orang lain, atau melalui dokumen (Sugiyono, 2011). Data primer dapat diperoleh misalnya dari angket, observasi, dan wawancara yang dilakukan oleh pengumpul data. Data sekunder dapat diperoleh dari sumber tertulis yang dapat dibagi atas sumber buku dan majalah ilmiah, sumber dari arsip, dokumen pribadi, dan dokumen resmi. Buku, skripsi, tesis, disertasi, jurnal, media massa, majalah, dan karya ilmiah lainnya sangat berguna bagi peneliti untuk menjajaki sebuah keadaan yang sedang diteliti.

\subsection{TEKNIK PENGUMPULAN DATA}

Teknik pengumpulan data yang penulis lakukan dalam penelitian ini adalah studi pustaka atau studi literatur dan wawancara. Dalam M. Subana dan Sudrajat (2005) disebutkan bahwa studi pustaka atau kajian literatur merupakan salah satu kegiatan penelitian yang mencakup memilih teori-teori hasil penelitian, mengidentifikasi literatur, dan menganalisis dokumen, serta menerapkan hasil analisis tadi sebagai landasan teori bagi penyelesaian masalah dalam penelitian yang dilakukan. Maksud dari kegiatan kajian literatur adalah mencari teori atau landasan berpikir yang tepat sebagai penguat proses penyelesaian masalah. Studi pustaka ini dilakukan dengan memanfaatkan secara maksimal bahan-bahan pustaka yang relevan untuk menjawab permasalahan penelitan ini. Selain itu juga dimaksudkan untuk mengetahui sudah sejauh mana penelitian yang dilakukan tentang masalah yang akan diteliti dan untuk meyakini bahwa penelitian yang akan ditempuh memungkinkan untuk dilakukan karena didukung oleh teori yang ada. Ruang lingkup kegiatan studi pustaka meliputi pengidentifikasian, penjelasan, dan penguraian secara sistematis dokumendokumen yang mengandung informasi yang berkaitan dengan masalah yang dibahas.

Melalui metode ini penulis mencoba mencari literatur yang berkaitan dengan penelitian yang dilakukan, khususnya tentang teori-teori yang menyangkut manajemen laba dan etika bisnis Islam untuk mempelajari berbagai data sumber tertulis dan menganalisis bagaimana etika bisnis Islam tersebut memandang manajemen laba. Dalam studi pustaka ini, penulis berfokus pada buku-buku dan jurnal bertopik majanemen laba, creative accounting, etika, etika bisnis Islam, agency theory, asymetris information.

Wawancara merupakan salah satu teknik pengumpulan data primer, wawancara adalah percakapan dengan maksud tertentu oleh dua pihak, yaitu pewawancara (interviewer) sebagai pengaju/pemberi pertanyaan dan yang diwawancarai (interviewee) sebagai pemberi jawaban atas pertanyaan itu. Wawancara yang dilakukan merupakan wawancara terbuka, para subjeknya mengetahui bahwa mereka sedang diwawancarai dan mengetahui pula maksud wawancara tersebut. Sedangkan bentuk pertanyaannya merupakan pertanyaan terbuka yang berkaitan dengan pendapat atau nilai (Basrowi \& Suwandi, 2008).

Penulis melakukan wawancara terhadap interviewee dalam dua bidang profesi, yaitu akademisi dan praktisi. Untuk akademisi, interviewee merupakan 
seorang dosen akuntansi, analisis laporan keuangan, dosen entrepreneur/etika bisnis Islam, dosen keuangan, perbankan, dan ekonomi Islam. Selanjutnya praktisi merupakan seorang officer departemen kebijakan akuntansi sebuah bank syariah di Indonesia dan seorang staf akuntansi dan pajak di sebuah perusahaan.

Dalam penelitian kualitatif, tingkat kecukupan (representasi) informan/ responden tidak ditentukan oleh jumlah atau kuantitas responden, tetapi lebih ditentukan oleh kualitas responden yang memberikan informasi. Para responden penelitian tersebut di atas dipandang cukup cakap dan layak untuk memberikan informasi yang diperlukan dalam penelitian ini.

\subsection{ANALISIS DATA}

Metode analisis data yang digunakan adalah dengan menggunakan pendekatan kualitatif deskriptif, yaitu dengan cara memaparkan informasi-informasi faktual berupa kata-kata, gambar, yang diperoleh dari kegiatan studi pustaka dan wawancara yang berhubungan dengan manajemen laba, etika bisnis Islam, dan pandangan etika bisnis Islam terhadap manajemen laba tersebut.

Penulis menganalisis berbagai teori dan praktik manajemen laba yang terjadi, berbagai pendapat tentang manajemen laba dari beberapa profesi. Selanjutnya menganalisisnya dari sudut pandang etika bisnis Islam untuk menghasilkan sebuah jawaban.

\section{MANAJEMEN LABA DALAM SUDUT PANDANG ETIKABISNIS ISLAM}

\subsection{TELAAH LITERATUR MANAJEMEN LABA DALAM TINJAUAN ETIKA BISNIS} ISLAM

Pada bahasan kali ini akan dipaparkan hasil dari telaah literatur yang dilakukan penulis terhadap data sekunder yang berkaitan dengan manajemen laba dalam tinjauan etika bisnis Islam. Rahayu Abdul Rahman, Asheq Rahman, Stephen Courtenay dari Massey University, Auckland, New Zealand, menulis sebuah paper dengan judul Religion And Earnings Management some Evidence from Malaysia. Paper tersebut ditulis berdasarkan observasi terhadap 1406 perusahaan dalam jangka waktu 2002-2006. Tujuan dari paper tersebut adalah untuk menguji hubungan antara nilai etika agama dengan manajemen laba. Dengan menggunakan pengukuran akrual abnormal, mereka menemukan bahwa perusahaan-perusahaan syariah di Malaysia mempunyai tingkat signifikan akrual abnormal yang lebih rendah daripada perusahaan non syariah counterpartnya. Ini berarti perusahaan syariah lebih tidak perlu untuk melakukan manipulasi melalui manajemen laba. "A common measure of accounting quality is abnormal accruals (Dechow and Schrand, 2002). Higher abnormal accruals are seen as a signal of earnings manipulation" (hlm.14). Pengukuran kualitas akuntansi yang biasa digunakan adalah abnormal akrual (Dechow dan Schrand, 2002). Abnormal akrual yang lebih tinggi menunjukkan sinyal manipulasi laba.

Perusahaan syariah yang dimaksud adalah perusahaan yang mengikuti etika perspektif Islam untuk aktivitas bisnis dan pelaporan keuangannya. 
Malaysia merupakan salah satu negara yang melaksanakan etika bisnis Islam, Malaysia memiliki Islamic Capital Market (ICM) ${ }^{3}$ yang mana sebuah perusahaan diklasifikasikan sebagai perusahaan syariah jika melaksanakan prinsip Islam pada aktivitas bisnisnya. Walaupun prinsip syariah diutamakan bagi muslim, namun dalam ICM tidak membeda-bedakan bisnis tersebut milik muslim atau nonmuslim, yang paling penting dan yang menjadi batasan adalah sesuai atau tidaknya bentuk bisnis tersebut, praktik keuangan dan tingkah laku sumber daya manusianya dengan prinsip-prinsip Islam.

Hasil penelitian Rahman et al menyebutkan bahwa "Overall, we find support for our hypothesis that Shariah firms have lower earnings management than non-Shariah firms (hlm.18). "We find support for our hypothesis that the earnings management of firms is negatively associated with the religious business norms and accountability processes of Shariah” (hlm.19). Hasil penelitian yang mereka lakukan sejalan dengan hipotesis bahwa perusahaan syariah memiliki manajemen laba yang lebih rendah daripada perusahaan non syariah. Hal tersebut didasarkan oleh hubungan negatif antara manajemen laba dengan norma bisnis syariah dan proses akuntansi syariah.

Sistem etika Islam yang mereka gunakan sebagai pedoman adalah sistem etika perspektif Islam berdasarkan firman Allah bukan berdasarkan persepsi individu atau komunitas tertentu. Sistem etika Islam tersebut memiliki empat nilai utama, yaitu unity, equilibrium, free will and responsibility (Naqvi, 1994). Hal ini konsisten dengan landasan teori yang digunakan penulis, yaitu etika bisnis Islam Beekun, 1996. Berdasarkan nilai unity, bisnis memperlakukan semua bagian sebagai satu kesatuan. Setiap orang harus diperlakuakn secara adil, tidak curang tanpa diskriminasi. Sedangkan konsep ekuilibrium menawarkan prinsip tanggungjawab sosial dan keadilan. Konsep free will memberikan manusia kebebasan untuk memilih, tetapi tetap harus mengikuti etika. Konsep pertanggungjawaban berhubungan dengan konsep kebebasan, kebebasan harus diimbangi dengan tanggung jawab individu dan kelompok. Tanggung jawab berkenaan dengan kewajiban untuk bertindak sesuai syariah.

Jika hasil penelitian di atas dihubungkan dengan sistem etika yang digunakan sebagai landasan yaitu etika bisnis Islam, maka dapat ditarik kesimpulan bahwa manajemen laba tidak sesuai dengan syariah atau sistem etika bisnis Islam. Hal tersebut didasarkan pada pernyataan yang merupakan temuan dari penelitian yang dilakukan Rahman et al yaitu Shariah firms have lower earnings management than non-Shariah firms, the earnings management of firms is negatively associated with the religious business norms and accountability processes of Shariah. Manajemen laba perusahaan syariah lebih rendah dari pada perusahaan non syariah, perusahaan syariah disini adalah perusahaan yang melaksanakan sistem etika Islam/prinsip syariah. Ini artinya, perusahaan syariah dengan sistem etika Islamnya mereduksi praktik manajemen laba, lebih rendahnya manajemen laba mengindikasikan bahwa manajemen laba tersebut tidak sesuai dengan etika bisnis Islam. Hal ini didukung oleh pernyataan bahwa manajemen laba memiliki hubungan negatif dengan norma bisnis Islam dan proses akuntansi syariah. Lagi pula rendahnya tingkat managemen laba 
menujukkan kualitas laba yang lebih baik, Malaysian firms seem to have lower earnings management or better quality earnings (hlm.18). Perusahaan Malaysia nampaknya memiliki manajemen laba yang lebih rendah atau kualitas laba yang lebih baik.

Penelitian sejenis dilakukan Rahayu Abdul Rahman (2012) yang dituangkan dalam thesisnya yang berjudul Religion Ethical Values and Earnings Quality: Some Evidence from Malaysia. Thesis tersebut mengambil sampel sebanyak 1621 perusahaan di Malaysia dengan jangka waktu antara 2000-2007. Rahman melakukan penelitian tersebut dengan tujuan untuk menguji hubungan antara nilai etika dalam agama, syariah, dan kualitas laba yang dilaporkan. Kualitas laba disini dilihat dari dua faktor yaitu manajemen laba dan konservatisme akuntansi. Secara lebih rinci tujuan penelitian tersebut adalah (1) untuk menguji pengaruh syariah terhadap manajemen laba riil dan manajemen laba akrual, (2) untuk menguji pengaruh syariah terhadap konservatisme akuntansi. Sehubungan dengan tujuan tersebut, penulis fokus kepada tujuan pertama yang berhubungan dengan manajemen laba.

Hasil penelitian tersebut mengungkapkan bahwa syariah memiliki hubungan signifikan negatif dengan manajemen laba akrual dan manajemen laba riil. Perusahaan syariah memiliki tingkat akrual diskresioner yang lebih rendah daripada perusahaan non syariah. Hal ini karena ada hubungan negatif antara syariah dengan akrual diskresioner, ini dapat diartikan bahwa ada hubungan negatif antara syariah dengan manajemen laba, berhubung akrual diskresioner merupakan salah satu teknik dalam manajemen laba.

Alasan mengapa perusahaan syariah memiliki kualitas laba yang lebih baik adalah karena etika bisnis Islam yang diterapkan pada perusahaan syariah tersebut. Etika bisnis Islam/syariah melarang berbisnis dengan cara yang tidak adil, etika bisnis Islam menekankan pada transparansi karena transparansi adalah salah satu pertanggungjawaban moral dalam Islam. Sistem etika Islam tersebut disematkan pada dua nilai utama yaitu unity (tauhid) dan justice (keadilan). Dua nilai utama tersebut membawa dampak besar sebagai pedoman dalam melaksanakan aktivitas ekonomi dan transaksi bisnis. Dengan dua nilai utama dalam sistem etika Islam tersebut, penelitian Rahman tersebut memberikan bukti bahwa etika bisnis Islam dapat membatasi praktik manajemen laba akrual dan manajemen laba riil.

Hasil penelitian Ibrahim menunjukkan bahwa dari sudut pandang etika secara umum terdapat dua pendapat yang bertolak belakang, yaitu yang menganggap wajar dan yang menganggap tidak etis, akan tetapi pendapat yang kedua lebih kuat.

Jika ditinjau dari sudut pandang etika, earnings management, yang didalamnya termasuk tindakan income smoothing (perataan laba) merupakan tindakan yang dapat menyesatkan pemakai laporan keuangan dengan menyajikan informasi yang tidak akurat, dan bahkan kadang merupakan penyebab terjadinya tindakan illegal, misalnya penyajian laporan keuangan yang terdistorsi atau tidak sesuai dengan sebenarnya (Wahyudin, 2003 dalam Ibrahim 2010, hlm.105) 
Berdasarkan pernyataan tersebut di atas, karena earnings management dapat menyesatkan pemakai laporan keuangan dengan adanya informasi yang tidak akurat bahkan mengakibatkan tindakan illegal, ini berarti tindakan tersebut tidak sesuai dengan etika bisnis Islam, selain juga bertentangan dengan kaidah fiqh muamalah. Unsur penipuan (tadlis) dan ketidakjelasan (gharar) merupakan unsur yang bertentangan dengan konsep adil. Hal ini konsisten dengan aksioma etika bisnis Islam Beekun (1996) yaitu konsep adil, equilibrium. Jika suatu bisnis bertentangan dengan konsep adil tersebut maka bisnis tersebut tidak sesuai dengan etika bisnis Islam.

Penelitian tentang manajemen laba dilakukan pula oleh Majdi Anwar Quttainah, Laing Song and Qiang Wu (2011). Tujuan dari penelitian yang berjudul Do Islamic Banks Employ Less Earnings Management? tersebut adalah untuk menguji apakah bank Islam berkemungkinan kecil mengolah labanya dan bagaimanakah pengaruh sistem tata kelola perusahaan, khususnya shariah supervisory boards terhadap perilaku manajemen laba dalam bank Islam. Sehubungan dengan penelitian ini, penulis fokus pada tujuan pertama yaitu apakah bank Islam berkemungkinan kecil dalam hal mengolah laba (earnings management).

Penelitian tersebut melibatkan sampel sebanyak 82 bank Islam dan 82 bank konvensional yang seluruhnya berjumlah 164 bank. Penelitian dilakukan dalam rentang waktu 1992-2008 di 11 negara, yaitu Bahrain, Mesir, Iran, Jordan, Kuwait, Lebanon, Qatar, Saudi Arabia, Sudan, Turkey, dan Uni Emirat Arab. Mereka menggunakan alat ukur utama manajemen laba dalam industri perbankan: menghindari kerugian laba, penyisihan kerugian pinjaman abnormal. Hasil dari penelitian Majdi Anwar et al (2011) menyebutkan bahwa bank Islam, kecil kemungkinannya melakukan manajemen laba dibandingkan bank konvensional. Bank Islam disini merupakan bank yang menerapkan tata kelola syariah, yang secara utuh menyediakan pedoman berdasarkan nilai agama dan menyediakan aturan untuk membatasi atau memandu dalam mengelola alokasi sumber daya, produksi, konsumsi, aktivitas pasar modal, dan juga distribusi kekayaan. Filosofi Islam, merepresentasikan etika bisnis dari sebuah sistem yang didasarkan pada nilai-nilai agama. Sistem ini digolongkan sebagai etika dan norma moral yang diakui oleh masyarakat. Berdasarkan hal tersebut, hasil penelitian menunjukkan bahwa agama memiliki dampak yang penting bagi manajer dalam membuat keputusan akuntansi.

Dalam papernya, Majdi Anwar et al juga menyebutkan bahwa dari hasil satistik bank Islam memilki sekitar 3\%-5\% lebih kecil kemungkinan menggunakan teknik menghindari kerugian dibandingkan dengan perusahaan sejenis yang dibandingkan dengannya. Selanjutnya, rata-rata penetapan kerugian pinjaman abnormal bank Islam 0,0002 lebih rendah daripada bank konvensional. Dua hal tersebut, penghindaran kerugian dan penyisihan kerugian pinjaman abnormal adalah indikator praktik manajemen laba dalam penelitian ini, maka dapat disimpulkan bahwa manajemen laba dalam bank Islam lebih kecil daripada bank konvensional. Kedua hasil ini signifikan secara statistik dan ekonomi, hal ini mengindikasikan bahwa hukum Islam (syariah) secara efektif memengaruhi 
manajer dalam membuat keputusan pelaporan keuangan. Hasil penelitian ini secara serempak selaras dengan penelitian-penelitian lain tentang manajemen laba dalam kaitannya dengan etika bisnis Islam.

\subsection{HASIL WAWANCARA TENTANG BAGAIMANA ETIKA BISNIS ISLAM MENINJAU MANAJEMEN LABA}

Diadakannya wawancara merupakan langkah untuk mengumpulkan data primer sebagai pendukung data sekunder dari studi pustaka dan telaah literatur yang dilakukan, maka penelitian ini diharapkan dapat memberikan kesimpulan yang lebih komprehensif, valid dan robust. Pembahasan hasil wawancara ini akan dimulai dengan ulasan pemahaman manajemen laba oleh masing-masing responden, karena pemahaman mereka terhadap manajemen laba akan memengaruhi penilaian mereka dari sudut pandang etika bisnis Islam.

Responden pertama seorang akademisi, dosen etika bisnis Islam, yang menyatakan bahwa manajemen laba tersebut merupakan sebuah aktivitas yang sebenarnya menginginkan ada kepentingan untuk perusahaan, baik itu untuk kepentingan maksimal (income maximization) atau keuntungan minimal (income minimization). Pemahaman ini sesuai dengan pengertian manajemen laba menurut Sulistiawan (2003) yaitu aktivitas badan usaha untuk memanfaatkan teknik dan kebijakan akuntansi guna mendapatkan hasil yang diinginkan, antara lain berupa penyajian nilai laba atau aset yang lebih tinggi atau lebih rendah, bergantung pada motivasi mereka melakukannya.

Sementara responden akuntan akademisi menyatakan bahwa manajemen laba itu intervensi manajemen terhadap laba yang ingin dibukukan atau ditetapkan oleh perusahaan, manajemen laba itu muncul karena adanya pilihan, adanya accrual accounting di akuntansi yang bisa memberikan peluang bagi manajemen untuk memilih metode akuntansi, kemungkinan dalam pemilihan metode akuntansi ini memunculkan potensi manajemen laba. Manajemen laba bisa bersifat hanya kosmetik yang tidak melibatkan arus kas, tapi ada juga manajemen laba yang sifatnya lebih kepada manipulasi laba yang melibatkan arus kas juga, hal ini lebih berbahaya. Kata berbahaya yang diungkapkan akuntan akademisi pada saat ditanya pemahamannya tentang manajemen laba, mengindikasikan bahwa ketika manajemen laba riil itu dilakukan maka akan ada pihak-pihak yang mendapatkan bahaya atau keugian.

Responden akademisi selanjutnya yang membidangi keuangan, perbankan dan ekonomi Islam menyatakan bahwa manajemen laba merupakan cara perusahaan melaporkan laba atau revenuenya dalam konteks agar laporan keuangan terlihat bagus dalam persepsi investor dan stakeholder yang menjadi pengguna informasi.

Responden praktisi, officer departemen kebijakan akuntansi sebuah bank syariah di Indonesia menyatakan praktik manajemen laba merupakan praktik pemilihan kebijakan akuntansi dari standar akuntansi yang ada yang secara alamiah dapat memaksimalkan utilitas atau nilai pasar perusahaan yang memang menjadi tugas akuntan ketika seorang akuntan tidak hanya mengurusi debit dan kredit saja. 
Responden lain yang bekerja sebagai staf tax and accounting sebuah perusahaan di Indonesia menyatakan bahwa praktik manajemen laba merupakan hal yang lumrah dilakukan sebagai strategi oleh pihak manajemen, perusahaan yang melakukan manajemen laba biasanya digunakan untuk meningkatkan bonus dan penghematan pajak.

Secara pribadi, beliau menyampaikan bahwa cenderung tidak setuju dengan praktik manajemen laba. Menurutnya, apapun motivasi dalam praktik manajemen laba ada unsur yang dirugikan. Motivasi pajak, motivasi penjualan saham supaya sahamnya laku dijual, motivasi utang agar mendapatkan pinjaman dari bank, motivasi bonus agar ketika direksi melihat laporan keuangan yang bagus maka manajer akan mendapatkan bonus, dalam hal tersebut semacam ada penipuan.

Konsisten dengan akademisi etika bisnis Islam, akuntan akademisi juga menyatakan bahwa beliau cenderung tidak setuju. Pernyataan tersebut didukung oleh pendapatnya bahwa laporan keuangan merupakan laporan yang harus mencerminkan realitas ekonomi yang sebenarnya dari suatu perusahaan. Pemilihan metode akuntansi yang tersedia di accrual accounting harus dipertimbangkan oleh manajemen agar bisa mencipatakan atau mencerminkan realitas ekonomi yang sebenarnya bagi perusahaan. Manajemen menerbitkan laporan keuangan dengan berbagai metode akuntansi yang tersedia agar bisa mencerminkan realitas ekonomi yang paling dekat, tidak untuk menentukan laba sesuai dengan kepentingan perusahaan atau bagi manajer itu sendiri. Atau dengan kata lain memenuhi unsur-unsur dalam karakteristik kualitatif laporan keuangan, yaitu dapat dipahami, relevan, keandalan, dapat diperbandingkan.

Akademisi keuangan, perbankan, dan ekonomi Islam secara diplomatis menyatakan bahwa manajemen laba sulit untuk dinilai setuju atau tidak setuju. Harus dilihat konteksnya terlebih dahulu, untuk apa manajemen laba tersebut dilakukan. Dalam teori agensi dijelaskan bahwa pada sebuah perusahaan terjadi asimetri informasi antara manajemen dengan pihak luar perusahaan, ada kondisi dan kejadian yang tidak terlihat oleh investor. Ketidakterlibatan tersebut mengakibatkan investor tidak memahami situasi yang dihadapi oleh manajemen sehingga ketika manajemen melaporkan secara apa adanya justru menimbulkan persepsi lain dan merugikan penilaiannya terhadap kinerja manjemen. Pada kondisi tersebut manajemen laba dilakukan untuk upaya mencerminkan realitas ekonomi dan dirasa masih logis. Namun bisa juga manajemen laba dilakukan untuk menutupi keburukan manajemen atau memberikan kesan yang sama sekali berbeda dengan kenyataan dan sifatnya misleading, memengaruhi keputusan investor. Pada keadaan seperti itu, beliau memberi pendapat bahwa hal tersebut jelas tidak terpuji, pernyataan tersebut mengindikasikan bahwa suatu hal yang tidak terpuji adalah suatu hal yang tidak disetujui. Namun sekali lagi, dua hal tersebut sulit untuk dipisahkan, sulit dibuktikan, dan tidak setiap orang mempunyai hak untuk melakukan pembuktian.

Menyikapi pernyataan bahwa selama masih dalam koridor standar akuntansi maka manajemen laba boleh/legal dilakukan, akademisi etika bisnis Islam menyampaikan bahwa jika dilihat dari versi akuntansi hal tersebut memang 
benar atau legal tetapi jika ada unsur ketidakjujuran maka itu akan menjadi masalah. Dalam versi etika bisnis Islam, selama ada yang dirugikan atau dizalimi maka tidak diperkenankan, tetapi jika tidak ada yang dizalimi, tidak ada unsur yang dirugikan maka tidak menjadi suatu masalah. Sementara akuntan akademisi memberikan komentar bahwa laporan keuangan tersebut tidak akan dipermasalahkana ketika diaudit karena masih dalam koridor standar akuntansi, misalnya ada pergantian metode di satu waktu, selama penggantian metode itu masih mengikuti standar akuntansi yang berlaku umum maka tidak akan dipermasalahkan ketika diaudit. Namun sebagai implikasinya, bisa membuat kualitas laporan keuangan menjadi turun.

Akuntan akademisi memberikan pandangan, seharusnya metode akuntansi yang tersedia digunakan untuk kepentingan publik, pembaca laporan keuangan, sehingga mereka mendapatkan informasi yang sesungguhnya, informasi yang bisa mencerminkan realitas ekonomi perusahaan yang sebenarnya. Sementara, saat ini manajemen laba banyak sekali digunakan sebagai kosmetik, mempercantik laporan keuangan. Sehingga secara tegas akuntan akademisi menyatakan bahwa manajemen laba dipandang tidak etis. Alasannya, manajemen laba bisa memberikan informasi yang tidak sesuai dengan aslinya, walaupun tekniknya legal secara PABU, tapi tidak dari sisi etika bisnis Islam. Dalam Islam tidak diperkenankan memberikan informasi yang tidak mencerminkan hal yang sesungguhnya, apalagi manipulasi laba yang kemudian memunculkan skandal akuntansi. Manajemen laba tidak mengangkat citra perusahaan namun justru menghancurkan perusahaan sampai tidak bisa eksis lagi, hal ini mengingatkan kita kepada kasus Enron dan KAP Arthur Andersson \& Co yang dengan sendirinya dijauhi para kliennya dan akhirnya tidak eksis lagi.

Selanjutnya menurut praktisi, staf tax and accounting sebuah perusahaan di Indonesia mengatakan etis atau tidaknya manajemen laba tergantung bagaimana cara pandang dan dari sisi mana kita memandangnya, akan menjadi etis bagi para manajemen, mungkin akan menjadi tidak etis bagi para pemegang saham, karena mereka merasa dibohongi manajemen. Pernyataan ini menunjukkan bahwa dalam praktik manajemen laba ada pihak-pihak yang merasa dibohongi, salah satunya adalah pemegang saham. Hal ini tidak sesuai dengan etika bisnis Islam yang mengedepankan kejujuran dan transparansi, tidak sesuai dengan prinsip adil dan kemanfaatan, tidak sesuai dengan spiritual corporate governance berupa shiddiq, amanah, tabligh. Selanjutnya beliau menyatakan manajemen laba boleh dilakukan, namun cara pandang tersebut merupakan cara pandang konvensional, karena ketika diminta pendapatnya dari sudut pandang etika bisnis Islam beliau menyatakan kurang memahaminya.

Praktisi officer kebijakan akuntansi bank syariah juga menyatakan manajemen laba itu etis selama tidak ada aturan dan ketentuan yang dilanggar dan tidak mengurangi kualitas laporan keuangan yang disyaratkan oleh KDPPLK, karena tidak melanggar suatu ketentuan apapun dan merugikan siapapun. Namun praktik manajemen laba memiliki kecenderungan mengurangi transparansi dan ada pihak yang merasa tidak menerima keadilan. Lebih lanjut beliau mengungkapkan hal tersebut ialah celah ketidakberesan dari ilmu 
akuntansi yang memang masih berparadigma kapitalisme. Sehubungan dengan sudut pandang etika bisnis Islam, beliau tidak menyatakan pendapatnya untuk menghindari adanya conflict of interest. Kecenderungan mengurangi transparansi yang diungkapkan tersebut dirasa kurang sesuai dengan konsep adil yang menghindari adanya kezaliman dan gharar serta bertentangan dengan shiddiq yang mengandung nilai-nilai transparansi, akuntabilitas (accountability), terbuka (disclosure), kredibilitas (credible), benar, jujur, dan andal (reliability).

Akademisi keuangan, perbankan dan ekonomi Islam menilai kesesuaian atau ketidaksesuaian manajemen laba dengan etika bisnis Islam berdasarkan firman Allah surat An Nisaa' ayat 135,

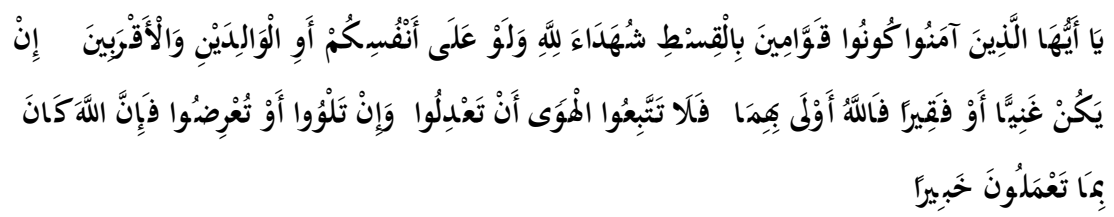

Wahai orang-orang yang beriman, jadilah kamu orang yang benarbenar penegak keadilan, menjadi saksi karena Allah biarpun terhadap dirimu sendiri atau ibu bapa dan kaum kerabatmu. jika ia[361] Kaya ataupun miskin, Maka Allah lebih tahu kemaslahatannya. Maka janganlah kamu mengikuti hawa nafsu karena ingin menyimpang dari kebenaran. dan jika kamu memutar balikkan (kata-kata) atau enggan menjadi saksi, Maka Sesungguhnya Allah adalah Maha mengetahui segala apa yang kamu kerjakan.

Menurut beliau, pada intinya seorang muslim itu harus bersaksi apa adanya, sekalipun itu merugikan dirinya dan merugikan keluarganya, itu sudah menjadi prinsip umum mengenai kesaksian. Artinya seorang muslim dalam bersaksi tidak terbatas pada kesaksian di pengadilan saja, tapi juga ketika transaksi termasuk dalam pelaporan keuangan. Dalam transaksi dibutuhkan kesimetrisan informasi antara pembeli dan penjual, ketika kita menjual barang ada cacatnya, kita harus memberitahu sekalipun nantinya si pembeli urung membeli, itu sudah menjadi risiko, kita tidak boleh menyembunyikan informasi. Artinya yang menjadi concern Islam adalah informasi yang simetris, tidak boleh menyembunyikan informasi yang memungkinkan orang untuk berubah pikiran. Itu etika dalam Islam, logikanya harus menyajikan apa adanya. Namun di tingkat operasional situasinya semakin sulit karena di dalam konsep/doktrin ekonomi sendiri manusia itu adalah makhluk yang selfish rasional, hal ini sudah dipahami oleh orang-orang. Investor selfish rasional, manajemen selfish rasional, dan masing-masing tahu bahwa counterpartnya selfish rasional. Manajemen memandang investor selfish rasional, manajemen memandang investor berpikir untuk keuntungannya sendiri. Jadi dalam pandangan ini walaupun manajemen sudah jujur pun ketika mengalami kerugian bisnis, maka investor akan mencaricari kesalahan manajemen. Investor berpikir dengan model yang sama pula 
terhadap manajemen, manajemen menginginkan keuntungan yang maksimal untuk dirinya sendiri. Manajemen punya potensi untuk menyembunyikan informasi yang semestinya diketahui oleh investor, sehinnga investor menekan manajemen karena mindset awalnya memang saling mencurigai.

Selanjutnya secara lebih detail hasil wawancara terhadap para responden dirangkum pada tabel 1 berikut ini: .

\section{Tabel 1. Hasil Wawancara}

\begin{tabular}{|c|c|c|}
\hline Responden & $\begin{array}{c}\text { Pemahaman Responden Terhadap } \\
\text { Manajemen Laba }\end{array}$ & $\begin{array}{l}\text { Pendapat Responden tentang Manajemen } \\
\text { Laba dalam Tinjauan Etika Bisnis Islam }\end{array}$ \\
\hline $\begin{array}{l}\text { Dosen Etika } \\
\text { Bisnis Islam }\end{array}$ & $\begin{array}{l}\text { Manajemen laba merupakan sebuah } \\
\text { aktivitas yang sebenarnya } \\
\text { men ginginkan ada kepentingan untuk } \\
\text { perusahaan, baik itu untuk } \\
\text { kepentingan maksimal (income } \\
\text { maximization) atau keuntungan } \\
\text { minimal (income minimization). } \\
\text { Pemahaman ini sesuai dengan } \\
\text { pen gertian manajemen laba men urut } \\
\text { Sulistiawan (2003) }\end{array}$ & $\begin{array}{l}\text { Manajemen laba tidak sesuai dengan etika bisnis } \\
\text { Islam karena etika bisnis Islam menjunjung tinggi } \\
\text { nilai kejujuran. Jika dari awal bisnis sudah } \\
\text { dibungkus dengan manajemen laba pada kondisi } \\
\text { perusahaan rugi namun dinyatakan untung, maka } \\
\text { lambat laun maka praktik tersebut akan diketahui } \\
\text { publik, dan disini ada pihak-pihak yang dirugikan } \\
\text { (merugikan dan dirugikan bertentangan den gan } \\
\text { aksioma etika bisnis Islam yaitu aksioma adil, } \\
\text { equilibrium). }\end{array}$ \\
\hline $\begin{array}{c}\text { Akuntan } \\
\text { Akademisi }\end{array}$ & $\begin{array}{l}\text { Manajemen laba merupakan } \\
\text { intervensi manajemen terhadap laba } \\
\text { yang ingin dibukukan atau ditetapkan } \\
\text { oleh perusahaan }\end{array}$ & $\begin{array}{l}\text { Secara tegas akuntan akademisi menyatakan } \\
\text { bahwa manajemen laba dipandang tidak etis. } \\
\text { Alasannya, manajemen laba bisa memberikan } \\
\text { in formasi yang tidak sesuai dengan aslinya, } \\
\text { walaupun tekniknya legal secara PABU, tapi } \\
\text { tidak dari sisi etika bisnis Islam. Dalam Islam } \\
\text { tidak diperkenankan memberikan informasi yang } \\
\text { tidak mencerminkan hal yang sesungguhnya, } \\
\text { apalagi manipulasi laba yang kemudian } \\
\text { memunculkan skandal akuntansi. }\end{array}$ \\
\hline $\begin{array}{c}\text { Dosen } \\
\text { Keuangan, } \\
\text { Perbankan, } \\
\text { dan Ekonomi } \\
\text { Islam }\end{array}$ & $\begin{array}{l}\text { Manajemen laba merupakan cara } \\
\text { perusahaan melaporkan laba atau } \\
\text { revenuenya dalam kon teks agar } \\
\text { lap oran keuan gan terlihat bagus } \\
\text { dalam persepsi investor dan } \\
\text { stakeholder yang men jadi pengguna } \\
\text { informasi. }\end{array}$ & $\begin{array}{l}\text { Manajemen laba tidak sesuai dengan etika bisnis } \\
\text { Islam berdasarkan firman Allah surat An Nisaa' } \\
\text { ayat 135, "Wahai orang-orang yang beriman, } \\
\text { jadilah kamu orang yang benar-benar penegak } \\
\text { keadilan, menjadi saksi karena Allah biarpun } \\
\text { terhadap dirimu sendiri atau ibu bapa dan kaum } \\
\text { kerabatmu......" }\end{array}$ \\
\hline $\begin{array}{c}\text { Officer } \\
\text { Departemen } \\
\text { Kebi jakan } \\
\text { Akuntansi } \\
\text { Sebuah Bank } \\
\text { Syariah }\end{array}$ & $\begin{array}{l}\text { Manajemen laba merupakan praktik } \\
\text { pemilihan kebijakan akuntan si dari } \\
\text { standar akuntansi yang ada yang } \\
\text { secara alamiah dapat memaksimalkan } \\
\text { utilitas atau nilai pasar perusahaan } \\
\text { yang memang menjadi tugas akun tan } \\
\text { ketika seorang akuntan tidak hanya } \\
\text { men gurusi debit dan kredit saja. }\end{array}$ & $\begin{array}{l}\text { Sehubungan dengan sudut pan dang etika bisnis } \\
\text { Islam, beliau tidak men yatakan pen dapatnya } \\
\text { untuk menghindari adanya conflict of interest. } \\
\text { Namun menurut pendapatn ya, praktik manajemen } \\
\text { laba memiliki kecen derungan men gurangi } \\
\text { transparan si dan ada pihak yang merasa tidak } \\
\text { menerima keadilan. Apa yang diungkapkan } \\
\text { tersebut dirasa kurang sesuai dengan konsep adil } \\
\text { yang menghin dari adanya kezaliman dan gharar } \\
\text { serta bertentangan den gan shiddiq yang } \\
\text { mengandung nilai-nilai transparansi, akuntabilitas } \\
\text { (accountability), terbuka (disclosure), kred ibilitas } \\
\text { (credible), ben ar, jujur, dan an dal (reliability). }\end{array}$ \\
\hline
\end{tabular}




\begin{tabular}{|c|l|l|}
\hline Responden & $\begin{array}{c}\text { Pemahaman Responden Terhadap } \\
\text { Manajemen Laba }\end{array}$ & $\begin{array}{c}\text { Pendapat Responden tent ang Manajemen } \\
\text { Laba dalam Tinjaua n Etika Bisnis Islam }\end{array}$ \\
\hline $\begin{array}{c}\text { Tax and } \\
\text { Staff }\end{array}$ & $\begin{array}{l}\text { Praktik manajemen laba merupakan } \\
\text { hal yang lumrah dilakukan sebagai } \\
\text { strategi oleh pihak manajemen, } \\
\text { perusahaan yang melakukan } \\
\text { manajemen laba biasanya digunakan } \\
\text { untuk men ingkatkan bonus dan } \\
\text { penghematan pajak. }\end{array}$ & $\begin{array}{l}\text { Respon den menyatakan kurang memahami } \\
\text { manajemen laba jika ditinjau dari etika bisnis } \\
\text { Islam. Namun dalam pendapatnya terdapat } \\
\text { pern yataan bah wa ada pihak yang merasa } \\
\text { dibohongi manajemen yaitu pemegang saham. } \\
\text { Karena ada pihak yang merasa diboh ongi, maka } \\
\text { hal ini tidak sesuai dengan etika bisnis Islam yang } \\
\text { mengedepankan kejujuran dan transparansi, tidak } \\
\text { sesuai dengan prinsip adil dan kemanfaatan, tidak } \\
\text { sesuai dengan spiritual corporate governance } \\
\text { berupa shiddiq, amanah, tabligh }\end{array}$ \\
\hline
\end{tabular}

4.1 ANALISIS DAN PEMBAHASAN MANAJEMEN LABA DALAM TINJAUAN ETIKA BISNIS ISLAM

Terdapat perbedaan pemahaman etis dan tanggung jawab sosial antara satu orang dengan orang lain dalam memahami suatu peristiwa tertentu. Perbedaan ini membuat apa yang dihasilkan antara satu orang dengan orang lain berbeda meski kedua orang ini melakukan atau menilai suatu hal yang sama. Alasan ini yang menjelaskan mengapa laporan keuangan disebut sebagai cermin perilaku etis dan tanggung jawab sosial orang yang menyusun informasi tersebut. Alasan ini pula yang menjadikan orang-orang memiliki penilaian yang berbeda terhadap praktik manajemen laba.

Ada hubungan sebab akibat yang dikembangkan untuk menjelaskan mengapa pemahaman etika dan tanggungjawab sosial seseorang dapat memengaruhi pemahaman orang tersebut terhadap manajemen laba. Hal ini didasari oleh kenyataan bahwa etika yang dipegang dan tanggungjawab sosial terhadap lingkungannya dapat memengaruhi keputusan seseorang untuk melakukan manajemen laba. Alasannya, pemahaman seseorang terhadap etika mempengaruhi pandangannya terhadap manajemen laba (Sulistyanto, 2008). Semakin positif pemahaman etis seseorang semakin tinggi pula pemahaman bahwa manajemen laba merupakan aktivitas yang sebaiknya tidak dilakukan, apalagi jika berujung pada skandal akuntansi. Sebaliknya, semakin negatif pemahaman etis seseorang maka semakin rendah pula pemahamannya bahwa manajemen laba merupakan aktivitas yang sebaiknya tidak dilakukan.

Apa yang dijelaskan di atas memang dapat diterima meski kenyataan yang terjadi tidak selamanya sama seperti konsep tersebut. Seorang manajer yang melakukan manajemen laba tidak selalu disebabkan oleh nilai-nilai etika yang dipegangnya rendah. Manajemen laba bisa terjadi karena adanya tekanan keuangan yang ditanggung oleh seorang manajer meskipun manajer tersebut memegang teguh nilai etika. Kaitannya dengan kasus tersebut, mungkin manajer tersebut memahami etika secara baik, namun etika yang ia pegang terkalahkan oleh tekanan keuangan. Akhirnya seorang manajer melakukan manajemen laba meskipun apa yang ia lakukan tersebut sebenarnya tidak sesuai jika dilihat dari kacamata etika (etika bisnis Islam). 
Ketidaksesuaian manajemen laba dengan etika bisnis Islam dapat dilihat dari telaah literatur dan hasil dari wawancara yang telah dilakukan. Berdasarkan berbagai literatur dikemukakan bahwa perusahaan syariah memiliki manajemen laba yang lebih rendah daripada perusahaan non syariah yang didasarkan pada hubungan negatif antara manajemen laba dengan norma bisnis syariah dan proses akuntansi syariah. Dalam sistem etika Islam nilai-nilai yang terkandung adalah nilai unity, equilibrium, free wiil, and responsibility, seperti telah dibahas dalam literatur-literatur penelitian yang menunjukkan antara manajemen laba dengan nilai tersebut memiliki hubungan negatif berarti terdapat ketidaksesuaian diantara keduanya. Hal ini serupa dengan penelitian sejenis yang mengungkapkan bahwa ada hubungan negatif antara syariah dengan manajemen laba, nilai yang digunakan dalam penelitian tersebut adalah unity and justice. Penelitian serupa menunjukkan bahwa bank Islam lebih kecil kemungkinannya dalam melakukan manajemen laba dibandingkan bank konvensional, hal ini karena hukum Islam (syariah) secara efektif memengaruhi manajer dalam membuat keputusan dalam menyusun laporan keuangan. Selanjutnya Ibrahim (2010) mengemukakan bahwa dalam manajemen laba terdapat unsur tadlis (penipuan) dan gharar (ketidakjelasan) karena ada pihak yang menyembunyikan informasi dari pihak lainnya (unknown to one party). Padahal dalam Islam, menurut akademisi etika bisnis Islam pula, bahwa dalam Islam segala sesuatu disampaikan secara riil tidak ada unsur penipuan karena hal tersebut jelas tidak sesuai dengan etika bisnis Islam, khususnya prinsip adil dan saling ridha.

Etika bisnis Islam merupakan suatu sistem etika yang menjunjung nilainilai luhur, sedangkan manajemen laba banyak memberikan dampak negatif. Konsep tauhid dan unity merupakan konsep yang menghindari tindakan yang tidak etis. Keadilan, equilibrium menghendaki kehidupan yang seimbang, menghasilkan keteraturan, keamanan sosial, menempatkan segala sesuatu pada tempatnya, dan tidak menimbulkan kerugian pada salah satu pihak, tidak merugikan dan dirugikan. Sedangkan manajemen laba memberikan dampak negatif pada perekonomian, mikro, makro, bahkan internasional. Adil juga diartikan sebagai keterbebasannya dari unsur gharar dan kezaliman, namun justru dalam manajemen laba timbul informasi yang tidak jelas, informasi yang unknowm to one party serta ada pihak-pihak yang mendapatkan kezaliman dari pihak lain karena informasi yang tidak fair tadi. Konsep free will and responsibility menghendaki kebebasan yang dimilki manusia digunakan secara bertanggungjawab serta masih dalam koridor aturan Allah, namun kasus-kasus yang terjadi menunjukkan bahwa kebebasan yang dimiliki digunakan untuk memenuhi kepentingan pribadi dan melakukan penipuan terhadap pihak lain (lihat PT Kimia Farma Tbk., Enron, Xerox, dll). Konsep ihsan, benevolence menghendaki kemanfaatan dunia dan akhirat, sedangkan manajemen laba justru banyak menimbulkan ketidakbermanfaatan banyak pihak. Selain itu manajemen laba yang diungkapkan mengurangi kualitas laporan keuangan, menurunkan kualitas laba, dan timbulnya informasi yang tidak simetris dirasa tidak sesuai dengan shiddiq, amanah, tabligh, fathonah yang mengandung arti transparan, 
akuntabilitas (accountability), terbuka (disclosure), kredibilitas (credible), benar, jujur, andal (reliability), keadilan, peduli, kesadaran, terpercaya, bertanggungjawab, setia kepada komitmen, sosialisasi, internalisasi, komunikasi, informasi, kepemimpinan, keteladanan, transfer knowledge, empati, konsisten, kompetensi (competence).

\subsection{SOLUSI ETIKA BISNIS ISLAM TERHADAP PRAKTIK MANAJEMEN LABA}

Secara normatif etika bisnis Islam telah memberikan penilaiannya bahwa tindakan manajemen laba tersebut tidak sesuai dengan etik bisnis Islam. Diharapkan bahwa manajemen laba yang dilakukan perusahaan syariah adalah manajemen laba dalam arti manajemen yang memiliki makna baik bukan manajemen yang maknanya telah tereduksi. Dalam hal ini perusahaan-perusahaan yang ingin meminimalisasi praktik manajemen laba bisa mengimplementasikan etika bisnis Islam sebagai nilai yang mendasari operasional perusahaan. Secara rasional perusahaan dengan standar etika yang tinggi akan jauh dari tindakan-tindakan yang menyimpang.

Sehubungan dengan motivasi manajemen laba, hendaknya secara etika bisnis Islam, manajemen laba yang dilakukan tidak semata-mata untuk meningkatkan keuntungan pribadi manajemen, tidak untuk mendapatkan bonus yang besar semata tapi lebih bagaimana mencerminkan realitas ekonomi perusahaan. Tidak untuk meminimalkan pajak yang harus dibayar perusahaan, pajak hendaknya dibayarkan sesuai kewajiban pajak perusahaan yang sebenarnya, hal ini justru bisa menciptakan ikon jujur pada perusahaan yang akhirnya akan meningkatkan nilai perusahaan itu sendiri. Sehubungan motivasi utang, menjaga perjanjian utang hendaknya tidak dilakukan dengan cara manipulasi melalui manajemen laba namun bagaimana perusahaan menjalankan operasinya secara riil. Begitu juga dengan motivasi perusahaan dalam penjualan saham, tidak dengan mengelabuhi calon investor dengan menyajikan kinerja yang seakan-akan bagus. Manajemen laba yang diharapkan memberikan dampak positif terhadap perusahaan tidak dilakukan dengan motivasi-motivasi yang buruk atau motivasi yang dapat menguntungkan satu pihak dan merugikan pihak lain. Manajemen laba yang positif dilakukan dengan tujuan untuk memberikan manfaat bagi semua stakeholder dan dilakukan tanpa melanggar etika bisnis Islam yang tidak hanya menghendaki keuntungan sebesar-besarnya namun bagaimana aktivitas bisnis juga memberikan berkah, dan manajemen laba yang dilakukan seharusnya tidak secara sengaja mengurangi kualitas laporan keuangan dan laba yang dilaporkan.

Perusahaan dapat menerapkan peraturan seperti misalnya UndangUndang Sarbanes Oxley secara maksimal dengan pengawasan dan pengendalian yang baik serta menerapkan etika bisnis Islam di dalam GCG perusahaan sebagai salah satu langkah untuk meminimalisasi tindakan-tindakan menyimpang secara etika atau kecurangan-kecurangan yang mungkin terjadi. Pelaku perusahaan yang peduli dan konsen terhadap etika akan cenderung bertindak sesuai dengan nilai-nilai yang terkandung dalam etika bisnis Islam. 
Secara garis besar, kesimpulan dari pembahasan pada bab ini adalah manajemen laba tidak sesuai dengan etika bisnis Islam. Sehingga dengan penerapan etika bisnis Islam itu sendiri maka perusahaan dapat meminimalisasi praktik manajemen laba. Seperti penjelasan sebelumnya bahwa etika dan agama dapat memberikan batasan perilaku manusia dan dapat memengaruhi seseorang dalam mengambil keputusan.

\section{PENUTUP}

\subsection{KESIMPULAN}

Kata manajemen sebenarnya memiliki nilai luhur seperti merencanakan, melaksanakan, dan mengendalikan suatu kegiatan untuk mencapai tujuan tertentu. Tetapi dalam konteks manajemen laba ini, makna manajemen yang sebenarnya memiliki makna luhur tadi telah tereduksi menjadi makna yang berkonotasi buruk yaitu mengatur, mengubah, mempermainkan, menata dan memanipulasi angka laba untuk mencapai tujuan tertentu. Meskipun memang pada tataran teori praktik manajemen laba masih dianggap legal ketika tidak bertentangan dengan PABU, akan tetapi jika ditinjau dari etika bisnis Islam maka praktik manajemen laba merupakan sebuah praktik yang dianggap tidak sejalan dengan nilai-nilai yang terkandung dalam etika bisnis Islam. Beekun \& Badawi (2005) menjelaskan bahwa bagi seorang muslim, Islam merupakan way of life, seorang muslim dalam melakukan seluruh aktivitasnya termasuk aktivitas berbisnis tetap harus berpegang pada nilai-nilai Islam yang bersandar pada $\mathrm{Al}$ Quran dan hadits.

\subsection{SARAN}

1. Agar CEO, manajemen, dan para pelaku bisnis memperhatikan dan menerapkan nilai-nilai yang terkandung dalam etika bisnis Islam dalam menjalankan bisnisnya. Karena dalam etika bisnis Islam berbisnis tidak hanya masalah mencari keuntungan yang sebesar-besarnya, akan tetapi etika bisnis Islam mengajarkan bahwa keberkahan merupakan hal yang sangat utama dalam menjalankan bisnis.

2. Menanamkan etika bisnis Islam kepada generasi penerus bangsa, karena akan berpengaruh pada karakter dan selanjutnya memengaruhi seseorang dalam mengambil keputusan.

3. Saran untuk penelitian selanjutnya adalah masih sangat perlu dilakukan penelitian pada responden yang lebih beragam dan melibatkan objek penelitian yang terdiri dari beberapa lembaga keuangan syariah dalam kurun waktu yang cukup lama, agar diharapkan dapat diperoleh hasil penelitian yang lebih bervariasi.

4. Perlu dilakukan penelitian selanjutnya tentang kajian Al-Quran dan hadits terhadap manajemen laba agar diharapkan dapat diperoleh hasil yang lebih valid dan robust. 


\section{DAFTAR PUSTAKA}

Al Qur'an Digital Versi 2.1. (t.thn.).

\section{Al Quranul Kariim.}

Badroen, F., Suhendra, Mufraeni, A., \& Bashori, A. D. (2007). Etika Bisnis dalam Islam. Jakarta: Kencana.

Basrowi, \& Suwandi. (2008). Memahami Penelitian Kualitatif. Jakarta: Rineka Cipta.

Beekun, R. I. (1996). Islamic Business Ethics. Herndon: International Institute of Islamic Thought.

Beekun, R. I., \& Badawi, J. A. (2005). Balancing Ethical Responsibility among Multiple Organizational Stakeholders: The Islamic Perspective. Journal of Business Ethics, 131-145.

Dechow, P. M., \& Skinner, D. J. (2000). Earnings Management: Reconciling The Views of Accounting Academics, Practitioners, and Regulators. American Accounting Association. Accounting Horizon Vol. 14 No. 2 , 235-250.

Dewan Standar Akuntansi Keuangan Ikatan Akuntansi Indonesia. (2009). Pernyataan Standar Akuntansi Keuangan. Jakarta: Ikatan Akuntansi Indonesia.

Hadits Web 4.0 Kumpulan \& Referensi Belajar Hadits. (t.thn.).

Halim, J., Meiden, C., \& Tobing, R. L. (2005). Pengaruh Manajemen Laba pada Tingkat Pengungkapan Laporan Keuangan pada Perusahaan Manufaktur yang Termasuk dalam Indeks LQ-45. SNA VIII Solo, 117-135.

Harahap, S. S. (2011). Etika Bisnis dalam Perspektif Islam. Jakarta: Salemba Empat.

. (2011). Teori Akuntansi. Jakarta: Rajawali Pers.

Ibrahim, A. (2010). Income Smoothing dan Implikasinya terhadap Laporan Keuangan Perusahaan dalam Etika Ekonomi Islam. Jurnal Media Syariah Vol. XII No. 24 , 102-119.

Ikatan Akuntansi Indonesia. (2009). Standar Akuntansi Keuangan . Jakarta: Salemba Empat. 
Inggarwati, K., \& Kaudin, A. (2010). Persepsi Etis Pelaku Akuntansi terhadap Praktik Manajemen Laba Berdasarkan Profesi Akuntansi dan Jender. Jurnal Manajemen Teori dan Terapan Tahun 3 No. 3 , 1-16.

Jensen, M. C., \& Meckling, W. H. (1976). Theory of The Firm: Managerial Behavior, Agency Cost and Ownership Structure. Journal of Financial Economics Vol. 3 No. 4 , 305-360.

Kamaludin, U. A., \& Alfan, M. (2010). Etika Manajemen Islam. Bandung: CV Pustaka Setia.

Kawedar, W. (2005). Sikap Etis Akuntan dan Pengguna Jasa Akuntan terhadap Praktik Manajemen Laba. Jurnal Akuntansi \& Auditing Vol. 01 No. 02 , 198-214.

Kieso, D. E., Weygandt, J. J., \& Warfield, T. D. (2002). Akuntansi Intermediate (10th ed.) (Emil Salim, Penerjemah). Jakarta: Erlangga.

Marzuqi, A. Y., \& Latif, A. B. (2010). Manajemen Laba dalam Tinjauan Etika Bisnis Islam. Jurnal Dinamika Ekonomi dan Bisnis Vol. 7 No. 1, 1-22.

Noor, J. (2011). Metodologi Penelitian: Skripsi, Tesis, Disertasi, dan Karya Ilmiah. Jakarta: Kencana.

Putra, S. J., \& Durachman, Y. (2009). Etika Bisnis dan Hak Kekayaan Intelektual. Jakarta: Lembaga Penelitian UIN Jakarta.

Rahman, R. A. (2012). Religius Ethical Values and Earnings Quality: Some Evidence from Malaysia, Thesis. New Zealand: Massey University.

Rahman, R. A., Rahman, A., \& Courtenay, S. Religion and Earnings Management: Some Evidence from Malaysia. New Zealand: Massey University.

Riduwan, A. (2010). Etika dan Perilaku Koruptif dalam Praktik Manajemen Laba: studi Hermeneutika. Jurnal Akuntansi dan Auditing Indonesia Vol. 4 No. 3 .

Robbins, S. P., \& Coulter, M. (2004). Manajemen (7th ed.) (T. Hermaya \& Harry Slamet, Penerjemah). Jakarta: Indeks.

Ross, S. A. (1973). The Economic Theory of Agency: The Principal's Problem. American Economic Association Vol. 63 No. 2 , 134-139.

Subana, M., \& Sudrajat. (2005). Dasar-Dasar Penelitian Ilmiah. Bandung : Pustaka Setia. 
Subramanyam, K. R., \& Wild, J. J. (2010). Analisis Laporan Keuangan (10th ed.). Jakarta: Salemba Empat.

Sugiyono. (2011). Metode Penelitian Kuantitatif, Kualitatif, dan $R \& D$. Bandung: Alfabeta.

Suhendro, S. (2006). Motivasi dan Etika Manajemen Laba. Forum Ekonomi Vol. IX No.2, 9-16.

Sulistiawan, D., Januarsi, Y., \& Alvia, L. (2011). Creative Accounting Mengungkap Manajemen Laba dan Skandal Akuntansi. Jakarta: Salemba Empat.

Sulistyanto, S. (2008). Manajemen Laba: Teori dan Model Empiris. Jakarta: PT. Grasindo.

Sutedi, A. (2012). Good Corporate Governance. Jakarta: Sinar Grafika.

Syahatah, H., \& Adh-Dhahir, S. M. (2005). Transaksi dan Etika Bisnis Islam. Jakarta: Visi Insani Publishing.

Ujiyantho, M. A., \& Pramuka, B. A. (Juli 2007). Mekanisme Corporate Governance, Manajemen Laba, dan Kinerja Keuangan: Studi pada Perusahaan Go Publik Sektor Manufaktur. Makalah pada Simposium Nasional Akuntansi X. Makasar: Universitas Hasanudin.

Utami, W. (2005). Pengaruh Manajemen Laba terhadap Biaya Modal Ekuitas: Studi pada Perusahaan Publik Sektor Manufaktur. SNA VIII Solo, 100116 .

Wahyuningsih, D. R. (2007). Hubungan Praktik Manajemen Laba dengan Reaksi Pasar atas Pengumuman Informasi Laba Perusahaan Manufaktur di Bursa Efek Jakarta, Tesis. Semarang: Universitas Diponegoro.

Yadiati, W. (2010). Teori Akuntansi Suatu Pengantar. Jakarta: Kencana. 